Dept. of Animal and Clinical Nutrition

Fac. of Vet. Med., Assiut Univ.

\title{
EVALUATION OF FULL-FAT SOYBEANS AND CORN GLUTEN MEAL AS A PROTEIN SOURCES IN BROILER DIETS \\ (With 8 Tables)
}

\author{
By \\ H.A. ABDEL-RAHEEM; A.N. SAYED; NABILA A. GAZIA \\ and S.M.A. EL MASWARY \\ (Received at 27/3/2005)
}
تقييم فول الصويا الخام ومسحوق جلوتين الأرة كمصادر للبروتين في علانق بدارى التسمين

حسن عباس عبل الرحيم ، عبل الباسط نصر سبل ، نبيله عبل الهادي جازبيه ، صادق المسوري

تم إجر اء ثلاثة محاو لات في هذه التجربة لتقيبم مدى الاستبدال الجزئي لمسحوق فول الصويا

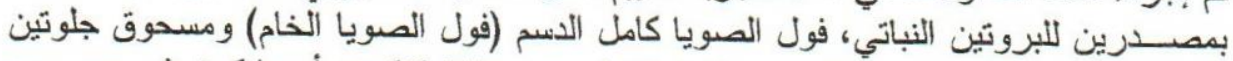

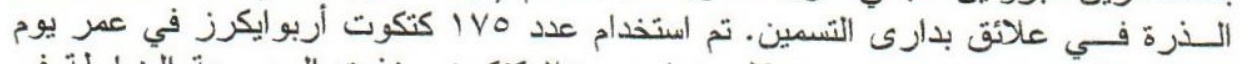

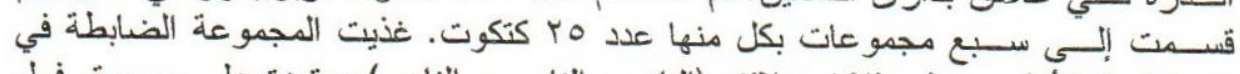

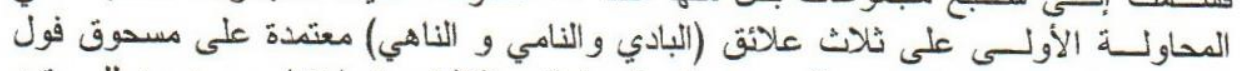

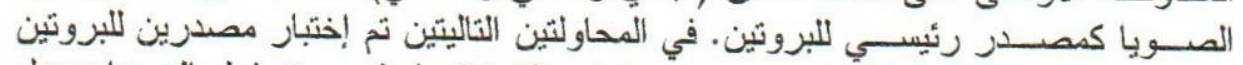

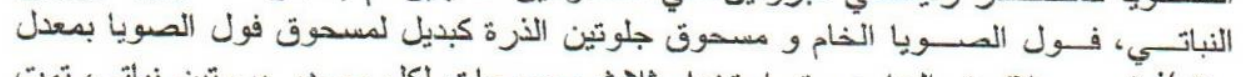

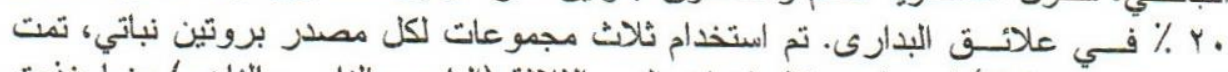

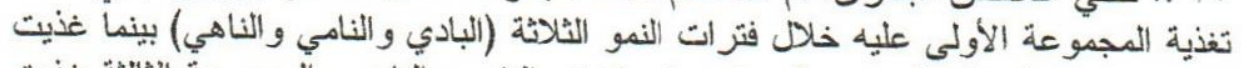

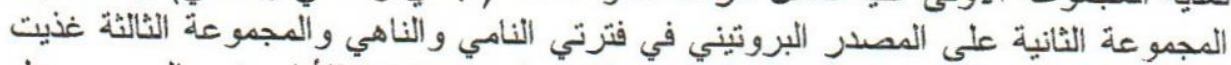

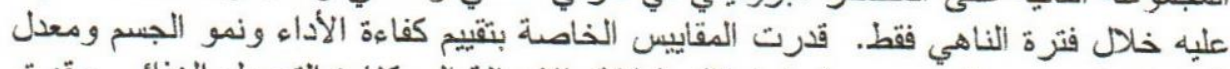

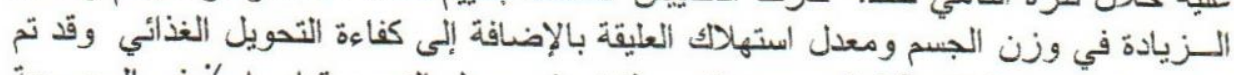

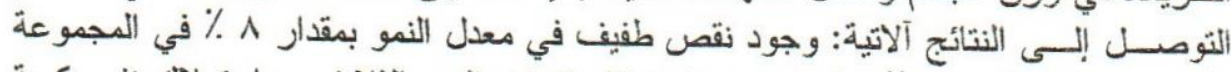

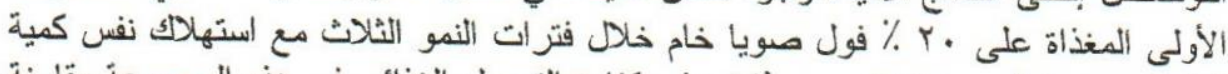

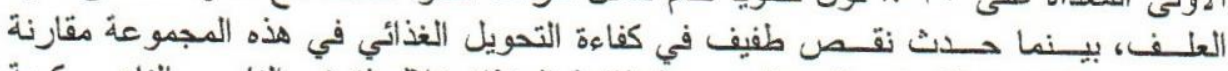

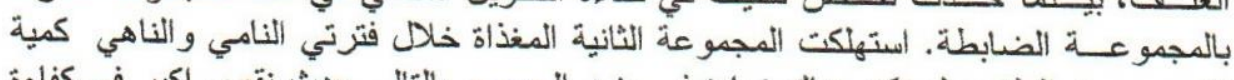

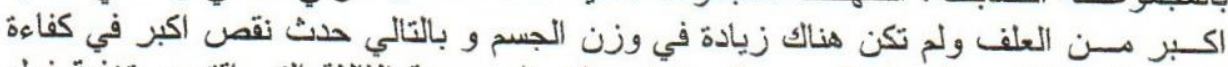

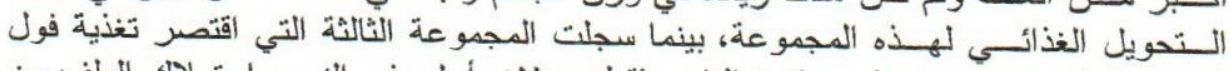

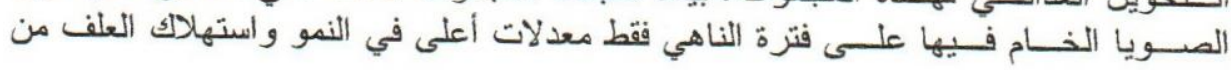




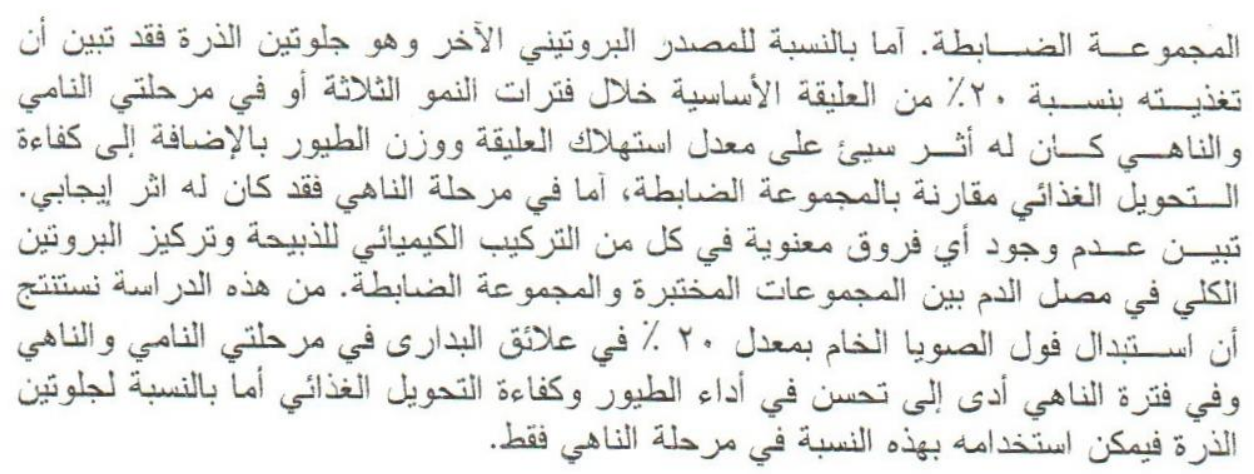

\section{SUMMARY}

This experiment was designed to trace the value of two plant protein sources, full-fat soybean (FFSB) and corn gluten meal (CGM) as a substitutes for soybean meal (SBM) in broiler diets in three main trials. A total number of 175 one day old chicks (Arbor acres) were weighed and randomly distributed into seven groups of 25 chicks each. A control group in the first trial was fed on three diets, the starter, grower and finisher based on SBM as the main protein source. In the other two main trials, two vegetable protein sources were tested as soybean meal substitutes, the full-fat soybeans and the corn gluten meal. Each of the plant proteins were used at a maximum rate of $20 \%$ in the broiler diets. For each SBM substitute, three groups were allotted, the first for feeding the substitute along the three feeding phases; starting, growing, and finishing; while the second for growing- finishing phases and the third for finishing period only. The growth performance, body weight development, weight gain, feed intake and feed conversion efficiency were assessed. In the first group of full-fat soybeans trial, there was a slight reduction in growth rate about $8 \%$, consuming the same amount of food as that of the control $(99.4 \%)$, and eventually slightly low food conversion efficiency. In the second group, more food consumed and less weight gained and by turn more lower feed conversion efficiency. In the third group and in which FFSB feeding was limited to the finishing period, growth rate was slightly higher than the control, as also the feed intake resulting in a feed conversion index nearly equal to that of the control. In trial III, feeding of broilers on $20 \%$ corn gluten meal during the three feeding phases of growth or during growing-finishing periods had adverse effect on the feed intake, body weight, in addition to feed utilization compared to control, while only confinement of CGM feeding to the finishing period is feasible. There were no differences in the 
chemical composition of carcass meat and serum total protein between different experimental groups in trials II \& III and control one. It is concluded that substitution of broiler diets with $20 \%$ heat processed soybeans during growing-finishing and finishing periods support chick performance and efficiency of feed utilization, while corn gluten meal could replace $20 \%$ of the diets in broilers during the finishing period only.

\section{Key words: Full-fat soybean, Corn gluten meal, broiler performance.}

\section{INTRODUCTION}

Poultry production enterprises gain is usually affected not only by the kind of diet formulation and needs satisfaction but also by feed prices, shortages, and the local running qualities. To guard against any extra expenses or low performances, feeds of low or bad quality should be denied and expensive feed substituted by others of low prices satisfying the same nutrients and qualities. Recently, there has been considerable interest in the use of the unextracted feed (full fat soybean) which combined the protein of the cake with high dietary energy values associated with the oil content to produce a raw material of some considerable value in poultry nutrition. Increased soybean production, competition from other oil seeds, and other factors have combined to make the use of full fat soybeans within the range of economic possibility. Properly cooked whole soybeans are capable of supporting adequate weight gains and efficiency of feed utilization when incorporated into the diets of broiler chicks (Waldroup, 1982; Sell, 1984; Zollitisch et al., 1992; Chohan et al., 1993, Lesson \& Atteh 1996; Hamilton \& McNiven, 2000, and Subuh et al., 2002).

There are isolated reports on the usefullness of corn gluten as a source for xanthophylls added to broiler chicks and layer diets to enhance skin and yolk pigmentation, but the data concerning its effect on growth of broilers are very scare. Corn gluten meal is a valuable byproduct of corn wet milling process, and the increment of this product production needs an evaluation to improve the utilization of corn gluten meal as a protein source in broiler diets (El-Deek et al., 2002). Beside its high protein content, corn gluten meal is low in fibre, has no anti nutritional factors and except for arginine and lysine and to a lesser extent methionine, has an adequate indispensable amino acid profile (Peter et al., 2000). On the basis of these thoughts, the plan of this 
experiment was designed to trace the value of two conventional plant protein sources, full-fat soybean (FFSB) and corn gluten meal (CGM) as a substitutes for soybean meal (SBM) in broiler diets.

\section{MATERIALS and METHODS}

\section{Experimental chicks}

A total number of 175 one day old chicks (Arbor acres) were weighed (initial weight of $55 \mathrm{~g}$ on the average) and randomly distributed into seven groups of 25 chicks each. The chicks were floor reared in an experimental room bedded by a layer of chaffed wheat straw and provided by clean feeders and waterers. All birds were kept under hygienic conditions and were subjected to a prophylactic vaccination and pharmacological program against viral and bacterial diseases specially New Castle virus disease.

\section{Experimental design:}

This experiment was designed to trace the value of two plant protein sources, full-fat soybean (FFSB) and corn gluten meal (CGM) as a substitutes for soybean meal (SBM) and fat in broiler diets in three main trials. The two vegetable proteins were used at a rate of $20 \%$ of the diet, a percentage large enough to achieve the ideal dietary density 3200 $\mathrm{Kcal} \mathrm{ME} / \mathrm{Kg}$ diet and to declare any bad effect on performance if any. For each SBM substitute, three groups were allotted, the first for feeding the substitute along the three feeding phases (starting, growing and finishing); while the second and third for the last $2^{\text {nd }}$ and $3^{\text {rd }}$ or last third respectively. The following table shown the design which put an age consideration in feeding.

\begin{tabular}{|c|c|c|c|c|c|c|c|}
\hline \multirow{4}{*}{ PHASE } & \multicolumn{7}{|c|}{ TRIAL } \\
\hline & $\begin{array}{c}\mathrm{I} \\
\text { SBM }\end{array}$ & \multicolumn{3}{|c|}{$\begin{array}{c}\text { Il } \\
\text { Full-fat soybean, } 20 \%\end{array}$} & \multicolumn{3}{|c|}{$\begin{array}{c}\text { III } \\
\text { Corn gluten meal, } 20 \%\end{array}$} \\
\hline & \multicolumn{7}{|c|}{ Groups } \\
\hline & Control & 1 & 2 & 3 & 1 & 2 & 3 \\
\hline $\begin{array}{c}\text { Starting } \\
(0-3 \text { weeks })\end{array}$ & + & + & - & - & + & - & - \\
\hline $\begin{array}{c}\text { Growing } \\
(3-5 \text { weeks })\end{array}$ & + & + & + & - & + & + & - \\
\hline $\begin{array}{c}\text { Finishing } \\
(5-7 \text { weeks })\end{array}$ & + & + & + & + & + & + & + \\
\hline
\end{tabular}




\section{Diets and feeding:}

In the three main trials, a control group in the first trial was fed on three diets, the starter, grower and finisher based on SBM as the main protein source. In the other two trials, three groups were assigned for each. The first group in each was fed three phases diets containing one SBM substitutes (heat processed soybeans or corn gluten meal), while in the second group, only the starter was based on SBM, and in the third group the starter and grower were both based on the SBM. In the grower and finisher of the second group and finisher of the third, the SBM substitutes were fed. FFSB and CGM were added at the rate of $20 \%$ in the second and third trials respectively (refer to the design table).

Firstly the used feeding-stuffs were analyzed for nutrients content following AOAC (1984) official method and all diets were formulated to contain the ME density and $\mathrm{CP}$ concentration recommended by NRC (1994) as shown in tables $1 \& 2$.

Table 1: Chemical composition (\%) and metabolizable energy value of the diet ingredients

\begin{tabular}{|l|c|c|c|c|c|c|c|}
\hline Ingredients & DM* & CP & EE & CF & Ash & NFE & $\begin{array}{c}\text { ME } \\
\text { Mcal/kg }\end{array}$ \\
\hline Ycllow corn & 88.7 & 8.6 & 3.2 & 3.0 & 1.3 & 72.6 & 3.350 \\
\hline Fish meal (herring) & 92.2 & 70.4 & 8.7 & 0.76 & 10.3 & 2.04 & 3.190 \\
\hline soybean oil meal & 88.3 & 44.0 & 0.9 & 8.0 & 5.2 & 30.2 & 2.230 \\
\hline Corn gluten meal & 89.0 & 59.3 & 2.7 & 1.5 & 1.76 & 23.74 & 3.720 \\
\hline Full fat soybean & 88.6 & 36.7 & 17.0 & 6.2 & 4.2 & 24.5 & 3.300 \\
\hline Urea & 99.0 & 290.6 & - & - & - & - & 2.700 \\
\hline Dried fat & 99.0 & - & 99.0 & - & - & - & 7.200 \\
\hline
\end{tabular}

* DM $=$ Dry matter $\quad \mathrm{CP}=$ crude protein

$\mathrm{NFE}=$ Nitrogen free extract

$\mathrm{EE}=$ Ether extract

$\mathrm{ME}=$ Metabolizable energy

The experiment extended for 7 weeks duration in three feeding phases, starting, through the first three weeks, growing from 3-5 weeks and finishing from 5-7 weeks of age. Performance during each period for different groups in the different trials was recorded. Chicks were fed ad libitum with free access to diets and fresh water through the experimental period. Birds were checked twice daily and the weight of dead birds was used to adjust the average feed consumption and body weights. 
Table 2: The physical and chemical composition (\%) of the experimental diets fed during the experimental period

\begin{tabular}{|l|c|c|c|c|c|c|c|c|c|}
\hline INGREDIENT & \multicolumn{3}{|c|}{ CONTROL DIETS } & \multicolumn{3}{c|}{ FULL- FAT SOYBEANS } & \multicolumn{3}{c|}{ CORN GLUTEN MEAL } \\
\hline & Starter & Grower & Finisher & Starter & Grower & Finisher & Starter & Grower & Finisher \\
\hline Physical & & & & & & & & & \\
composition & & & & & & & & & \\
Yellow corn & 45.50 & 58.79 & 67.51 & 47.9 & 60.55 & 69.3 & 65.6 & 72.62 & 76.66 \\
Soybean meal & 36.94 & 27.57 & 21.32 & 19.74 & 10.56 & 4.31 & 6.19 & - & - \\
Fish meal & 4.0 & 4.0 & 4.0 & 4.0 & 4.0 & 4.0 & 4.0 & 4.0 & - \\
Dried fat & 10.06 & 6.78 & 4.66 & 4.90 & 2.07 & - & 0.10 & - & - \\
Full-fat soybean & - & - & - & 20.0 & 20.0 & 20.0 & - & - & - \\
Corn gluten meal & - & - & - & - & - & - & 20.0 & 20.0 & 20.0 \\
Dicalcium phosph & 1.29 & 0.90 & 0.60 & 1.30 & 0.80 & 0.55 & 1.44 & 0.95 & 0.81 \\
Ground limestone & 1.44 & 1.37 & 1.40 & 1.40 & 1.43 & 1.34 & 1.48 & 1.54 & 1.60 \\
Common salt & 0.37 & 0.27 & 0.21 & 0.36 & 0.26 & 0.20 & 0.36 & 0.26 & 0.23 \\
Lysine & - & - & - & - & - & - & 0.53 & 0.33 & 0.40 \\
Methionine & 0.10 & 0.02 & - & 0.10 & 0.02 & - & - & - & - \\
Premix* & 0.30 & 0.30 & 0.30 & 0.30 & 0.30 & 0.30 & 0.30 & 0.30 & 0.30 \\
\hline Calculated chemical & & & & & & & & & \\
composition and & & & & & & & & & \\
energy value & & & & & & & & & \\
Crude protein & 22.98 & 20.00 & 18.00 & 22.96 & 0.01 & 18.01 & 23.03 & 20.92 & 18.45 \\
ME (Kcal/kg diet) & 3200 & 3200 & 3200 & 3200 & 3200 & 3200 & 3207 & 3304 & 3312 \\
Calori/protein ratio & 139.2 & 160.0 & 177.8 & 139.4 & 160.0 & 178.0 & 139.3 & 157.9 & 179.5 \\
Methionine & 0.50 & 0.38 & 0.34 & 0.50 & 0.38 & 0.34 & 0.54 & 0.51 & 0.43 \\
Meth. +cystine & 0.86 & 0.70 & 0.63 & 0.85 & 0.70 & 0.63 & 0.95 & 0.89 & 0.79 \\
Lysine & 1.33 & 1.10 & 0.96 & 1.32 & 1.10 & 0.96 & 1.33 & 1.00 & 0.85 \\
Arginine & 1.50 & 1.26 & 1.10 & 1.49 & 1.25 & 1.10 & 0.98 & 0.81 & 0.66 \\
Leucine & 1.92 & 1.74 & 1.62 & 1.92 & 1.73 & 1.61 & 3.08 & 2.94 & 2.77 \\
Calcium & 1.03 & 0.90 & 0.32 & 1.02 & 0.90 & 0.80 & 1.00 & 0.90 & 0.80 \\
Total phosphorus & 0.66 & 0.57 & 0.50 & 0.67 & 0.56 & 0.50 & 0.66 & 0.53 & 0.45 \\
Available phosph. & 0.45 & 0.36 & 0.30 & 0.46 & 0.35 & 0.30 & 0.45 & 0.35 & 0.30 \\
\hline
\end{tabular}

* Vigora premix (Vitamins and minerals)

\section{The tested parameters:}

\section{Growth performance and feed conversion:}

The amount of feed consumed was weekly recorded in each of the different groups. The average amount consumed by each bird was calculated by dividing the weekly consumed food by its respective number of birds in each group at this week. Regarding the development of the body weight and weight gain, the birds were individually weighed every week and the live weight changes were taken as the criteria of the effect of the different treatments, and as a measure for growth. The standard deviations and errors were calculated. The absolute weight of the bird gives an idea about the body weight development during the experimental period, the growth was measured and expressed in percentage relative to the body weight in order to compare the different groups in relation to its relative rate of growth. 
The amount of feed consumed was divided by the body weight gain of the bird in order to calculate the rate of feed conversion. Experimental crude data were subjected to several statistical analysis, from which the means, standard errors were calculated and differences were tested for significancy using $(\mathrm{t})$ test.

\section{Blood samples, carcass traits, and biochemistry:}

Five randomly selected birds from each group were slaughtered at the end of the experiment for carcass traits, chemical composition analysis, and blood samples collections. Feed but not water was removed from birds 12 hours prior to slaughtering. A blood specimen was collected from each of the slaughtered birds of all the groups at the end of the experiment. The blood samples were alloted to clot at ambient temperature, centrifuged for 10 minuets at $3000 \mathrm{rpm}$, and serum from each sample was extracted. The serum samples $(1 \mathrm{ml} / \mathrm{vial})$ were kept at $20^{\circ} \mathrm{C}$ until biochemical parameters were measured. Dressed carcass as the weight of the slaughtered birds after removal of feathers, head and feet but including all the offals, (edible or not) was recorded. The weights of some internal organs of birds including gizzard, proventriculus, liver, spleen and heart were recorded at the end of the experiment. The biochemical parameters, including total serum protein and its fractions (albumin and globulin) and urea were determined using standard test kits supplied by Biomerieux (Baines / France).

\section{Monetary value:}

Total production cost was calculated including prices of one day old chicks, feeding, heating, veterinary care, management and housing. Selling price was calculated by multiplying total live body weight of the birds produced by the price per unit weight commonly offered in the market.

Net revenue $=$ Price of body weight - Total production costs

Economic feed efficiency $(\mathrm{EFE})=\frac{\text { Net revenue }}{\text { Total production costs }}$

Relative economic feed efficiency (REFE) $=\frac{\text { EFE of group }}{\text { EFE of control }} \times 100$

\section{RESULTS and DISCUSSION}

The results obtained for broiler performance in terms of body weight development, feed intake, weight gain and feed conversion are 
presented in tables 3, 4\&5. Chemical composition of broiler meat and serum parameters are revealed in tables $6 \& 7$. The economical evaluation of broiler performance in different experimental groups is shown in table 8 .

The chicks in the first group were fed on starter, grower and finisher diets based on yellow corn and dried fat as sources for energy, SBM and fish meal (FM) as sources for protein. The performance of chicks on these diets was recorded in the first trial (trial I) and considered the control to which the other trials will be compared. The second and third (II \& III) trials were designed to extract the value of FFSB (dry-heated processed) and CGM as a substitutes for SBM and fat in broiler diets.

\section{Chick performance:}

\section{The full-fat soybean (FFSB) test:}

In the first group (feeding at 1 day of age) FFSB reduced significantly the weight of the chicks after 2 weeks of feeding where the weight reached $89 \%$ of that of the control group. The reducing effects got worst on the following three weeks where the weights reached 81.7, $79.3 \& 80.0 \%$ of the control weights respectively. In the sixth and seventh weeks, the chicks tried to get adapted to the supplement as they become old enough to overcome the anti-nutritional factors or others if any. The FFSB weights were 86.8 and $92.3 \%$ that of the control in the $6^{\text {th }}$ and $7^{\text {th }}$ weeks. In group 2 the substitution had an effect after 1 week of feeding (at the $4^{\text {th }}$ week of age), got worst the next week $\left(5^{\text {th }}\right.$ week of age) and tried to stand up the last two weeks, the finishing phase, reaching a weight nonsignificantly different from that of the control. In group 3, feeding FFSB in the finisher diet had no effect on body weight development and the chicks were old enough to cope with any decreasing effect.

Concerning the weight gain, there were significant differences between the different experimental groups during the first, second and third feeding periods. In the starting period only the first group, fed the FFSB, had the significantly lowest gains, while the control and groups 2 $\& 3$ had nearly equal gains. In the growing phase, only the third group kept in contrast with the control while groups $1 \& 2$ fed the substitute scored the lowest gains. In the finishing period, the first and second groups compensated and surpassed the control by about $17.4 \& 18.6 \%$, while the third group did not show any negative effect but on the contrary a positive one to the degree the gain reached $115.2 \%$ of that recorded in the control. The compensatory growth in groups $1 \& 2$ has 
been interpreted to be due to the increased digestibility of energy and other nutrients in the FFSB with the age development of the chickens (Agunbiade, 2000), but the more realistic interpretation is the increase in efficiency of feed utilization. The total body weight gains in the three groups of trial II were $2150.6,2214.1 \& 2402.6 \mathrm{~g}$ in the 7 weeks in comparison with $2334.5 \mathrm{~g}$ in the control.

The chicks replicated their initial weights 42.51 times in the control in the seven weeks, and 39.90,41.05 \& 44.17 in the three groups of trial II scoring differences in weight of $-184.71 \mathrm{~g}$ in group $1,-121.18$ in group 2 and $+687.65 \mathrm{~g}$ in group 3 (Table 3 ). It can be concluded that FFSB can be fed starting from the grower diets especially if there is cost reduction and starting from the finisher with no adverse effects but, on the contrary, there may be more gain in weight.

These results are nearly supported by the work of Schaible et al. (1979) who stated that properly cooked whole soybeans are capable of supporting adequate weight gains and efficiency of feed utilization when incorporated into the diets of broiler chicks. Also Waldroup, (1982); Sell, (1984); Zollitisch et al. (1992); Chohan et al. (1993), Lesson \& Atteh (1996), and Subuh et al. (2002) proved that properly processed full-fat soybean was capable of supporting performance similar to that obtained from chickens fed diets based on dehulled solvent extracted soybean meal without any adverse effect on body weight, feed conversion and dressing percentage. Katoch et al. (1997) attributed the better growth response and feed conversion in birds kept on heatprocessed soybean diets to the higher feed intake and better physiological utilization.

Feeding FFSB at 1 day of age in group 1 of trial II had no effect on feed consumption for the first two weeks, while in the third it reduced intake by about $9 \%$ when compared with the control. The reducing effect became more clear in the fourth week $(84.6 \%)$ and the chicks tried to get adapted to the supplement in the last three weeks of feeding. Feed intake shot up to $95.5 \%$ of the control in the fifth and to 104.0 and $114.6 \%$ in the sixth and seventh weeks. Referring to table 16, the starting and growing phases are the phases of reduction while the finishing phase the period of compensation making a collective rate of intake in the seven weeks nearly as that of the control. On the contrary in group 2 the FFSB feeding not only had no effect in the fourth and fifth weeks but also had an increasing effect on the sixth and seventh weeks by $11 \& 14 \%$, giving a collective rate of feeding slightly more than that of the control by about $5 \%$. In group 3 , feeding the whole beans in the finishing period 
increased intake in the sixth week of age by $5.2 \%$ and in the seventh by $17.2 \%$, making a collective increase in the seven weeks of $3.9 \%$. On the reverse Papadopoulos (1987) and Papadopoulos and Vandoros (1988) found that the incorporation of whole soybeans in replacement for soybean meal and fat reduced feed consumption without affecting weight gain. Popescu and Criste, (2003) found that average food consumption was lower than the group fed diet based on corn, SBM and fish meal, while Benabdeljelil (2002) detected no differences in terms of consumption. In our experiment the case is different, it did not affect feed consumption or slightly increased it in the whole period of fattening and decreased the weight gain if fed for the three phases or the last two and slightly increased the gain if fed in the finishing phase. So it could not say as a rule on an absolute basis but conditioned by the age of the bird and of course the percentage of substitution.

In the first group of FFSB trial it is a slight reduction in growth rate about $8 \%$ (body weight at 7 weeks of age $92.3 \%$ of that of the control), consuming the same amount of food as that of the control (99.4\%), and eventually slightly high food conversion index (2.39 compared to 2.21 in control). In the second group, more food consumed and less weight gained and by turn more higher feed conversion index (2.45). In the third group and in which FFSB feeding was limited to the finishing period, growth rate was slightly higher than the control, as also the feed intake resulting in a feed conversion index nearly equal to that of the control (2.24\& 2.21 respectively). Benabdeljelil (2002) said that chickens received extruded beans tended to display better growth and conversion indices than the control. The results appear conflicting but it is the age of feeding and percentage of addition which determines the effect.

\section{The corn gluten meal (CGM) test:}

In the first group of the third trial, which was fed on CGM from 1 day of age and for the 7 weeks of experimentation, the body weight was negatively affected from the first week of feeding. The rate was so decreased to the extent that the body weight reached only $59 \%$ of that of the control. Along the seven weeks, the rate got more affected week after week till the body weight reached $23 \%$ of that of the control group giving a body weight of $549 \mathrm{~g}$ at the end of the experiment. In the second group CGM was introduced in the diet and fed at the age of 3 weeks, the beginning of the growing stage. The average body weight of the group was $91.3 \%$ of that of the control one at the age of 3 weeks and steeply decreased to $66.7 \%$ at the age of 4 weeks and after one week of 
feeding the new supplement. The rate continued decreasing to reach $51.1 \%$ at the age of 7 weeks. In the third group the effect of feeding CGM in the finishing stage has a slight decreasing effect and the weight was on the average $84.6 \%$ of that of the control. In table 5, the weight gains were significantly different from that of the control group in the three phases in group 1, growing and finishing in group 2, and in the finishing in group 3. The total body gains in the seven weeks of feeding were $2334.35 \mathrm{~g}$ in the control, $493.00 \mathrm{~g}$ in group 1 of the CGM trial, $1165.77 \mathrm{~g}$ in group 2 and $1990.06 \mathrm{~g}$ in group 3, with group 1 the lowest followed by 2 . In the starting phase, the control group replicated the initial weight 13.6 times compared to $5.1,12.5 \& 13.8$ in the three groups of trial III respectively. The replicates at the end of the growing phase were 28.5 for the control, and $6.9,16.1 \& 29.1$ for CGM groups. At the end of the finishing period the figures were 42.5, 9.7, $21.8 \& 37.4$ in the same respective order.

Corn gluten meal is high in protein, low in fiber and has no antinutritional factors and is a good source of methionine and cystine. On the contrary of our results Owing et al., (1988) found no significant effect on weight gain when compared to corn-soybean meal control diet and could successfully substitute up to $10 \%$ of diet for growing turkey hens. Also Babidis et al. (2002) found no effect on body weight and ElDeek et al. (2002) stated that SBM can be replaced by CGM up to $75 \%$ in plant broiler chick diets but with the addition of probiotic and phytase enzyme. On the other hand, Sasse and Baker (1973) mentioned that there is little information on amino acids availability in CGM, Mendonca \& Jensen (1991); Holsheimer \& Janssen, (1991); Jensen (1991); and Surisdiarto \& Farrell (1991) found that its use markedly increased leucine levels relative to isoleucine and valine. Higher levels of leucine was reported to reduce body weight in birds (Waldroup et al., 2002). The high content of leucine seems to be the only factor incriminated especially when lysine supplementation in diets is considered.

Feeding the CGM supplement from the start of the experiment to the end of the seven weeks, in group 1, had a clear effect on feed consumption. It reduced the intake by about $32 \%$ in the first and second weeks when compared with the control and by an average reducing rate of about $47 \%$ in the rest of the five weeks, making a total consumption of about $55 \%$ of the control. The chicks seemed to be unable to adapt to the excess of leucine and the imbalance of amino acids characterizing the CGM supplement. In the second group the negative effect of the CGM feeding started also from the first week of addition, the fourth 
week, and the reducing effect reached to about $50 \%$. It continued at this rate till the seventh week where the chicks tried to compensate for and the consumption reached $60 \%$ of that of the control. On total, the chicks consumed in the seven weeks about $63 \%$ of that consumed by the control. Confining the feeding of CGM to the finishing period in the third group was less effective in reducing feed intake as the reduction was about 28.5 in the sixth week and $22 \%$ in the seventh, making a total consumption in the whole experimental period $90 \%$ of that of the control. On the contrary, Babidis et al. (2002) did not find any effect for CGM on daily feed consumption while Waldroup et al. (2002) mentioned that reduction in feed intake is due to changes in the texture of the diet.

Referring to Table 5, the feed conversion indices in the different groups of trial III and control point to the efficiency of food to be converted to body weight. The indices in the groups were larger than that of the control meaning that reduction in body weight was not only due to reduced feed consumption but also due to the lower efficiency of utilization probably due to the imbalance of amino acids and excess of leucine. In overall the 7 weeks of experimentation the indices were 5.74, 2.80 and 2.34 for the three CGM groups with only the last two are comparable to the control one (2.21) but with referring to the body weight at 7 weeks of age and the reduced feed intake, only confinement of CGM feeding to the finishing period is the feasible. Babidis et al. (2002) found no effect on feed conversion ratio as well as Owing et al. (1988) on feed efficiency. The inconsistency in the results may be due to the feeding of a high percentage of the supplement (20\%), an amount the chicks could not bear its amino acids imbalance and bad texture and palatability.

\section{Chemical composition of the meat:}

There were no differences between different experimental groups in the percentages of DM, CP, EE and ash of broiler meat, but with a trend for increased ether extract in the FFSB groups compared with control. Lazaro et al. (2002) reported that the level of 20\% FFSB up to one week prior to sacrifice can be used without detriment to the quality of the carcass, on the contrary, Chohan et al. (1993) recorded higher values for the dry matter, protein and carcass energy contents of the birds fed SBM diet than those fed full fat soybean meal. However, Popescu and Criste (2003) have noticed that FFSB diet assured an increased crude protein percentage inside chicken meat. Also the percentages of DM, CP, EE and ash of the meat were nearly similar in 
groups fed CGM diets in trial III and control one (Table 6) this means that corn gluten meal can not affect the quality of the meat composition.

\section{Serum parameters:}

At the end of the experiment, protein parameters in the serum of the experimental groups (Table 7) showed no differences in the total protein and albumin values between different experimental FFSB groups (trial II) as it ranged from 3.68 to $4.26 \mathrm{~g} / \mathrm{dl}$ and 3.22 to $3.94 \mathrm{~g} / \mathrm{dl}$ respectively compared with 4.19 and 3.39 for the control group (trial I). On the other hand, group fed on FFSB supplemented diet during finishing period recorded the lowest values for globulins $(0.32 \mathrm{~g} / \mathrm{dl})$ compared with control group $(0.80 \mathrm{~g} / \mathrm{dl})$. The total protein and albumin values revealed no differences among the CGM groups (trialII) at the end of the experimental period. Differences were recorded in the globulin values and lowest value was recorded with the first group fed on CGM supplemented diet throughout the whole experiment.

Economical evaluation (Monetary value):

Feeding full-fat soybean during whole experimental period reduced economical feed efficiency by about $16 \%$ when compared with the control. The reducing effect became more clear in chicks fed on FFSB during growing-finishing phase $(77.11 \%)$. On the contrary, the addition of $20 \%$ FFSB in the finisher diets of broilers had an increasing economical feed efficiency by about $4.5 \%$ when compared with control. Substitution of finisher broiler diets by $20 \%$ CGM decreased economical feed efficiency by about $15.5 \%$ compared with control as shown in table 8 .

Thus, it could be concluded that substitution of broiler diets with $20 \%$ properly cooked whole soybeans during growing-finishing and finishing periods support chick performance and efficiency of feed utilization, while corn gluten meal could replace $20 \%$ of the diets in broilers during the finishing period only.

\section{REFERENCES}

Agunbiade, J.A. (2000): Utilization of two varieties of full fat and simulated soybeans in meal and pelleted diets by broiler chickens. Journal of Science of Food and Agriculture 80: 15291537.

AOAC (Association of Official Analytical Chemists) (1984): Official Methods of Analysis (14 ${ }^{\text {th }}$ ed.) AOAC, Washington, DC. 
Babidis, V.; Florou-paneri, P.; Kufidis, D.; Christaki, E.; Spais, A.B. and Vassilopoulos, $V$. (2002): The use of corn gluten meal instead of herring and meat meal in broiler diets and its effect on performance, carcass fatty acid composition and other carcass characteristics. Archiv fur Geflugelkunde, 66 (4): 145$150 \mathrm{pp}$.

Ben abdeljelil, $K$. (2002): Le soja extrudé. Un nouvel outil por la nutrition avicole. FISA seminar. Dawajine. Casablanca, Morocco. 8 pp.

Chohan, A.K.; Hamilton, R.M.G.; McNiven, M.A. and Macleod, J.A. (1993): High protein and low trypsin inhibitor varieties of full fat soybeans in broiler chicker starter diets. Can. J. Anim. Sci. 73: 401-409.

EL. Deek, A.A.; Osman, M.; AL-Harthi, M.A.; Yakout, H.M. and Hassan, E.Y. (2002): Influence of pelleting, phytase and probioties on the performance and carcass composition of broilers fed diets containing corn gluten meal. Annual Meeting and Food Expo-Anaheim, California. Session 46 F, Nutrition.

Hamilton, R.M. and McNiven, M.A. (2000): Replacement of soybean meal with roasted full fat soybeans from high-protein or conventional cultivars in diets for broiler chickens. Canadian Journal of Animal Science 80: 483-488.

Holsheimer, J.P. and Janssen, W.M.M.A. (1991): Limiting amino acids in low protein maize-soybean meal diets fed to broiler chicks from 3-7 weeks of age. Br. Poult. Sci. 32:141-158.

Jensen, L.S. (1991): Broiler performance as affected by intact Proteins versus synthetic amino acids. Proceedings Georgia Nutrition conference Atlanta, GA. PP 83-89.

Katoch, B.S.; Katoch, R.C. and Mahajan, N.C. (1997): Effect of feeding heat treated soybean to chicks. Indian J. Anim. Sci. 47 (1): 3841.

Lazaro, R.; Mateos, G.G.; Latorre MaAngeles and Piquer, J. (2002): Whole soybeans in diets for poultry. American Soybean Association. Brussels, Belgium. 43 pp.

Lesson, S.J. and Atteh, J.O. (1996): Response of broiler chicks to dietary full-fat soybeans extruded at different temperatures prior to and after grinding. An. Feed. Sci. Tech. 57: 239-245.

Mendonca, C.X. and Jensen, L.S. (1989): Influence. Of valine level on performance of older broilers fed a low protein diet supplemented with amino acids. Nutr. Rep. Int., 40:247-252. 
N.R.C. (1994): Nutrient requirements of poultry. $9^{\text {th }}$ ed National Academy press, Washington, D.C., USA

Owings, W.J.; Sell, J.L.; ferket, P. and Hasiak, R.J. (1988): Growth performance and carcass composition of turkey hens fed corn gluten feed. Poult. Sci. 67: 585-589.

Papadopoulos, G. (1987): Full fat soybeans in poultry diets. American Soybean Association Brussels, Belgium, 12 pp.

Papadopoulos, G.; Vandoros, S. (1988): Dietary estimation of full-fat soybean on broiler fattening during the summer. Epitheorese Zootehnikes Epistemes, 7: 17-31

Peter, C.M.; Han, Y.; Boling-frankenbach, S.D.; parsons, C.M. and Baker, D.H. (2000): Limiting order of amino acids and the effects of phytase on protein quality in corn gluten meal fed to young chicks. J. Anim. Sci. 78 (8): 2150-2159.

Popescu, A. and Criste, R. (2003): using full fat soybean in broiler diets and its effect on the production and economic efficiency of fattening. Journal of central European Agriculture, 4(2): 167174.

Sasse, C.E. and Baker, D.H. (1973): Availability of sulfur amino acids in corn and corn gluten meal for growing chicks. J.Anim. Sci. 37:1351-1355.

Schaible, P.J. (1979): Poultry Feeds and Nutrition. Avian Publishing Company Inc., Westport, Connecticut. Third printing.

Sell, J. (1984): Use of soybeans in poultry diets (unpublished data; referenced by Monari, 1994).

Subuh, A.M.H.; Motl, M.A.; Fritts, C.A. and Waldroup, P.W. (2002):

Use of various ratios extruded full fat soybean meal and dehulled solvent extracted soybean meal in broiler diets. International, Journal of Poult. Sci. 1 (1): 9 -12.

Surisdiarto, H.S. and Farrell, D.J. (1991): The relationship between dietary crude protein and dietary lysine requirement by broiler chicks on diets with and without the "ideal" amino acid balance. Poult. Sci., 70: 830-836.

Waldroup, P.W. (1982): Whole soybeans for poultry feeds. Worlds Poult. Sci. J., 38: 28-35.

Waldroup, P.W.; Kersey, J.H. and Fritts, C.A. (2002): influence of branched-chain amino acid balance in broiler diets. International journal of poultry science, 1(5): 136-144.

Zollitisch, W.; Wetscherek, $W$. and Lettner, F. (1992): Use of full fat soybeans in broiler diets. Arch. Geflugelk, 56: 256-263. 
Table 3: Body weight development of broiler chicks in trials II and III compared with control (trial I)

\begin{tabular}{|c|c|c|c|c|c|c|c|}
\hline \multirow[t]{2}{*}{ WEEKS } & \multirow{2}{*}{$\frac{\text { TRIAL I }}{\text { Control }}$} & \multicolumn{3}{|c|}{ TRIAL II } & \multicolumn{3}{|c|}{ TRIAL III } \\
\hline & & 1 & 2 & 3 & 1 & 2 & 3 \\
\hline \multirow[t]{2}{*}{0} & 56.2 & 55.3 & 55.3 & 55.6 & 56.4 & 56.0 & 54.6 \\
\hline & $\pm 0.56^{\mathrm{a}}$ & $\pm 0.62^{\mathrm{a}}$ & $\pm 0.51^{\mathrm{a}}$ & $\pm 0.66^{\mathrm{a}}$ & $\pm 0.62^{\mathrm{a}}$ & $\pm 0.66^{\mathrm{a}}$ & $\pm 0.62^{\mathrm{a}}$ \\
\hline \multirow[t]{2}{*}{1} & 185.3 & 182.9 & 205.3 & 200.0 & 109.4 & 191.8 & 200.0 \\
\hline & $\pm 4.03^{b}$ & $\pm 6.17^{b}$ & $\pm 6.19^{\mathrm{a}}$ & $\pm 5.00^{\mathrm{a}}$ & $\pm 4.06^{c}$ & $\pm 6.31^{\mathrm{ab}}$ & $\pm 5.22^{\mathrm{a}}$ \\
\hline \multirow[t]{2}{*}{2} & 390.6 & 349.4 & 412.9 & 391.2 & 180.6 & 377.6 & 388.8 \\
\hline & $\pm 10.45^{\mathrm{a}}$ & $\pm 14.23^{c}$ & $\pm 14.32^{\mathrm{a}}$ & $\pm 9.85^{\mathrm{a}}$ & $\pm 9.76^{d}$ & $\pm 12.85^{b}$ & $\pm 10.50^{b}$ \\
\hline \multirow[t]{2}{*}{3} & 766.5 & 626.5 & 758.8 & 754.1 & 286.5 & 700.0 & 752.9 \\
\hline & $\pm 14.06^{\mathrm{a}}$ & $\pm 25.57^{b}$ & $\pm 23.01^{a}$ & $\pm 20.81^{\mathrm{a}}$ & $\pm 16.56^{c}$ & $\pm 24.67^{b}$ & $\pm 18.00^{\mathrm{a}}$ \\
\hline \multirow[t]{2}{*}{4} & 1204.1 & 955.3 & 1071.2 & 1214.7 & 344.7 & 802.9 & 1206.5 \\
\hline & $\pm 20.88^{\mathrm{a}}$ & $\pm 41.4^{b c}$ & $\pm 26.54^{b}$ & $\pm 24.34^{\mathrm{a}}$ & $\pm 21.20^{d}$ & $\pm 30.57^{c}$ & $\pm 33.64^{a}$ \\
\hline \multirow[t]{2}{*}{5} & 1604.7 & 1283.5 & 1337.6 & 1552.9 & 387.6 & 898.8 & 1592.4 \\
\hline & $\pm 26.17^{\mathrm{a}}$ & $\pm 36.76^{b}$ & $\pm 38.62^{b}$ & $\pm 29.52^{\mathrm{a}}$ & $\pm 22.32^{d}$ & $\pm 36.50^{c}$ & $\pm 37.86^{\mathrm{a}}$ \\
\hline \multirow[t]{2}{*}{6} & 2044.1 & 1774.7 & 1812.9 & 1975.3 & 458.2 & 972.4 & 1708.8 \\
\hline & $\pm 37.54^{\mathrm{a}}$ & $\pm 58.04^{b}$ & $\pm 38.1^{\mathrm{b}}$ & $\pm 50.42^{\mathrm{a}}$ & $\pm 30.42^{d}$ & $\pm 40.58^{c}$ & $\pm 47.4^{b}$ \\
\hline \multirow[t]{2}{*}{7} & 2390.6 & 2205.9 & 2269.4 & 2458.2 & 549.4 & 1221.8 & 2044.7 \\
\hline & $\pm 46.73^{\mathrm{a}}$ & $\pm 75.56^{b}$ & $\pm 42.3^{b}$ & $\pm 60.99^{\mathrm{a}}$ & $\pm 34.31^{\mathrm{e}}$ & $\pm 46.8^{d}$ & $\pm 50.90^{c}$ \\
\hline $\begin{array}{c}\text { Times of } \\
\text { initial }\end{array}$ & 42.51 & 39.90 & 41.05 & 44.17 & 9.70 & 21.80 & 37.40 \\
\hline
\end{tabular}

Figures in the same row having the same superscripts are not significantly different $(\mathrm{P}<0.05)$

Table 4: The feed consumption ( $\mathrm{g} / \mathrm{chick}$ ) of the experimental groups in trials II and III compared with control (trial I)

\begin{tabular}{|c|c|c|c|c|c|c|c|}
\hline \multirow{2}{*}{$\begin{array}{c}\text { PERIOD IN } \\
\text { WEEKS }\end{array}$} & TRIAL I & \multicolumn{3}{|c|}{ TRIAL II } & \multicolumn{3}{c|}{ TRIAL III } \\
\cline { 2 - 8 } & Control & 1 & 2 & 3 & 1 & 2 & 3 \\
\hline $0-1$ & 173.0 & 169.5 & 186.5 & 183.0 & 117.5 & 174.5 & 180.0 \\
$1-2$ & 414.5 & 425.0 & 418.5 & 425.5 & 283.5 & 424.0 & 418.0 \\
$2-3$ & 675.3 & 615.5 & 641.5 & 645.0 & 333.0 & 634.0 & 651.0 \\
$3-4$ & 873.2 & 738.5 & 866.0 & 863.5 & 391.5 & 434.0 & 843.5 \\
$4-5$ & 909.4 & 869.0 & 915.0 & 881.5 & 498.8 & 452.0 & 980.5 \\
$5-6$ & 1055.3 & 1097.5 & 1171.0 & 1110.0 & 597.0 & 511.5 & 755.5 \\
$6-7$ & 1068.4 & 1224.0 & 1219.0 & 1252.5 & 612.5 & 643.5 & 830.5 \\
\hline $\mathbf{0 - 7}$ & $\mathbf{5 1 6 9 . 1}$ & $\mathbf{5 1 3 9 . 0}$ & $\mathbf{5 4 1 7 . 5}$ & $\mathbf{5 3 7 0 . 0}$ & $\mathbf{2 8 3 3 . 8}$ & $\mathbf{3 2 7 2 . 5}$ & $\mathbf{4 6 5 9 . 0}$ \\
\hline
\end{tabular}


Table 5: Chick performance of experimental groups in trials II and III compared with control (trial I)

\begin{tabular}{|c|c|c|c|c|c|c|c|}
\hline \multirow{2}{*}{$\begin{array}{l}\text { PERIOD } \\
\text { IN } \\
\text { WEEKS }\end{array}$} & \multirow{2}{*}{$\frac{\text { TRIAL I }}{\text { Control }}$} & \multicolumn{3}{|c|}{ TRIAL II } & \multicolumn{3}{|c|}{ TRIAL III } \\
\hline & & 1 & 2 & 3 & 1 & 2 & 3 \\
\hline \multicolumn{8}{|l|}{ Feed intake } \\
\hline $0-3$ & 1262.8 & 1210.0 & 1246.5 & 1262.5 & 734.0 & 1232.5 & 1249.0 \\
\hline $3-5$ & 1782.6 & 1607.5 & 1781.0 & 1745.0 & 890.3 & 886.0 & 1824.1 \\
\hline $5-7$ & 2123.7 & 2321.5 & 2390.0 & 2362.5 & 1209.6 & 1155.0 & 1586.1 \\
\hline $0-7$ & 5169.1 & 5139.0 & 5417.5 & 5370.0 & 2833.9 & 3273.5 & 4659.2 \\
\hline \multicolumn{8}{|c|}{ Weight gain } \\
\hline $0-3$ & 710.2 & 571.2 & 703.5 & 698.5 & 230.1 & 644.0 & 698.3 \\
\hline & $\pm 13.77^{\mathrm{a}}$ & $\pm 25.07^{\mathrm{b}}$ & $\pm 22.68^{\mathrm{a}}$ & $=20.41^{\mathrm{a}}$ & $\pm 16.22^{\mathrm{c}}$ & $\pm 24.3^{\mathrm{ab}}$ & $\pm 17.59^{\mathrm{a}}$ \\
\hline $3-5$ & 838.2 & 657.1 & 578.8 & 798.8 & 101.2 & 198.8 & 839.4 \\
\hline & $\pm 22.77^{\mathrm{a}}$ & $\pm 19.17^{\mathrm{b}}$ & $\pm 31.13^{b}$ & $\pm 26.05^{3}$ & $\pm 10.74^{\mathrm{d}}$ & $\pm 17.68^{\circ}$ & $\pm 26.93^{2}$ \\
\hline $5-7$ & 785.9 & 922.4 & 931.8 & 905.3 & 161.8 & 322.9 & 452.4 \\
\hline & $\pm 36.5 i^{b}$ & $\pm 43.68^{\mathrm{a}}$ & $\pm 22.48^{\mathrm{a}}$ & $\pm 42.47^{\mathrm{a}}$ & $\pm 16.14^{\mathrm{e}}$ & $\pm 23.91^{\mathrm{d}}$ & $\pm 22.47^{\circ}$ \\
\hline $0-7$ & 2334.4 & 2150.6 & 2214.1 & 2402.6 & 493.0 & 1165.8 & 1990.1 \\
\hline & $\pm 46.84^{\mathrm{a}}$ & $\pm 75.17^{\mathrm{b}}$ & $\pm 42.11^{\mathrm{b}}$ & $\pm 61.19^{\mathrm{a}}$ & $\pm 34.09^{\mathrm{e}}$ & $\pm 46.59^{d}$ & $\pm 50.71^{c}$ \\
\hline \multicolumn{8}{|c|}{ Feed conversion } \\
\hline $0-3$ & 1.77 & 2.11 & 1.77 & 1.80 & 3.19 & 1.91 & 1.79 \\
\hline $3-5$ & 2.12 & 2.44 & 3.07 & 2.18 & 8.80 & 4.46 & 2.17 \\
\hline $5-7$ & 2.70 & 2.51 & 2.56 & 2.60 & 7.48 & 3.58 & 3.51 \\
\hline $0-7$ & 2.21 & 2.39 & 2.45 & 2.24 & 5.74 & 2.80 & 2.34 \\
\hline
\end{tabular}

Figures in the same row having the same superscripts are not significantly different $(P<0.05)$

Table 6: Chemical composition (\%) of broiler meat in trials II and III compared with control (trial I)

\begin{tabular}{|c|c|c|c|c|}
\hline \multirow{2}{*}{$\begin{array}{c}\text { TRIALS \& } \\
\text { WEEKS }\end{array}$} & \multirow{2}{*}{ DM } & \multicolumn{3}{|c|}{ ON DM BASIS } \\
\cline { 3 - 5 } & & CP & EE & Ash \\
\hline Trial I & & & & \\
(Control) & 25.64 & 83.82 & 12.50 & 3.56 \\
\hline Trial II & & & & \\
Group 1 & 25.97 & 81.77 & 14.35 & 3.85 \\
Group 2 & 26.40 & 82.42 & 13.98 & 3.88 \\
Group 3 & 25.61 & 82.02 & 14.02 & 3.92 \\
\hline Trial III & & & & \\
Group 1 & 23.58 & 80.80 & 14.90 & 4.27 \\
Group 2 & 23.98 & 80.50 & 15.13 & 4.31 \\
Group 3 & 25.91 & 82.25 & 13.55 & 4.16 \\
\hline
\end{tabular}


Table 7: Serum protein parameters of the chicks in trials II and III compared with control (trial I)

\begin{tabular}{|c|c|c|c|c|c|c|c|}
\hline \multirow{2}{*}{ PARAMETERS } & TRIAL I & \multicolumn{3}{|c|}{ TRIAL II } & \multicolumn{3}{c|}{ TRIAL III } \\
\cline { 2 - 8 } & Control & $\mathbf{1}$ & $\mathbf{2}$ & $\mathbf{3}$ & $\mathbf{1}$ & $\mathbf{2}$ & $\mathbf{3}$ \\
\hline $\begin{array}{c}\text { Total protein } \\
\text { (g/dl) }\end{array}$ & $\mathbf{4 . 1 9}$ & 3.68 & 4.05 & 4.26 & 3.43 & 3.71 & 3.98 \\
$\begin{array}{c}\text { Albumin } \\
\text { (g/dl) } \\
\text { Globulin } \\
\text { (g/dl) }\end{array}$ & $\mathbf{3 . 3 9}$ & 3.22 & 3.38 & 3.94 & 3.17 & 3.16 & 3.27 \\
\hline
\end{tabular}

Table 8: Economical evaluation of broiler performance in different experimental groups compared with control

\begin{tabular}{|c|c|c|c|c|c|c|c|}
\hline \multirow[t]{2}{*}{ PARAME-TERS } & \multirow{2}{*}{$\frac{\text { TRIAL I }}{\text { Control }}$} & \multicolumn{3}{|c|}{ TRIAL II } & \multicolumn{3}{|c|}{ TRIAL III } \\
\hline & & 1 & 2 & 3 & 1 & 2 & 3 \\
\hline Total feed cost (L.E) & 11.35 & 10.86 & 11.54 & 11.58 & 5.53 & 9.88 & 9.88 \\
\hline $\begin{array}{l}\text { Total production } \\
\text { cost (L.E) }\end{array}$ & 13.85 & 13.36 & 14.04 & 14.08 & 8.03 & 12.38 & 12.38 \\
\hline $\begin{array}{l}\text { Body weight } \\
\text { (g/chick) }\end{array}$ & 2390.6 & 2205.9 & 2269.4 & 2455.2 & 549.4 & 1221.8 & 2044.7 \\
\hline $\begin{array}{l}\text { Price of body weight } \\
\text { (L.E) }\end{array}$ & 19.12 & 17.64 & 18.16 & 19.67 & 4.40 & 9.77 & 16.36 \\
\hline Net revenue (L.E) & 5.27 & 4.28 & 4.12 & 5.59 & -3.63 & 0.41 & 3.98 \\
\hline $\begin{array}{l}\text { Economic feed } \\
\text { efficiency }(\%)\end{array}$ & 38.05 & 32.04 & 29.34 & 39.70 & - & - & 32.15 \\
\hline $\begin{array}{c}\text { Relative economic } \\
\text { feed efficiency } \%\end{array}$ & 100 & 84.20 & 77.11 & 104.34 & - & - & 84.49 \\
\hline
\end{tabular}

